\title{
Correction to: The work of the Konrad- Adenauer-Stiftung (KAS) in Northeast Asia
}

\author{
Stefan Samse, Rabea Brauer, Alexander Badenheim, Peter Hefele ${ }^{*}$ and David Merkle
}

\author{
The original article can be found \\ online at https://doi.org/10.1186/ \\ s40856-019-0046-0. \\ * Correspondence: peter.hefele@kas. \\ de \\ Konrad-Adenauer-Stiftung e.V., \\ Berlin, Germany
}

\section{Correction}

In the original publication of this article [1] some errors were made in the section of 'The People's Republic of China' due to typesetting mistakes, the correct content is as below. The errors in this Correction and some other typos have been updated in the original article. The publisher apologizes for the inconvenience caused to our authors and readers.

\section{The People's Republic of China}

The Konrad-Adenauer-Stiftung has been active in the People's Republic of China since the 1980s. The first office to which a German representative was posted was opened in Beijing in 1996. A second representation followed in Shanghai in 2001. In addition, a regional project addressing the key subject of energy security and climate change in the Asia-Pacific region was launched in 2015, based in Hong Kong.

The work of the project offices in Beijing and Shanghai focuses on strengthening Sino-German understanding and partnership, and on promoting bilateral exchange between China and Germany in the areas of politics, science, business, law and social sciences. KAS also seeks to contribute to the sustained success of China's economic reform process and to the dismantling of regional disparities.

The KAS Beijing Office focuses on promoting policy exchange and on developing and expanding channels and formats of political dialogue. German and European experts from the realms of politics, business and academia are brought together with Chinese party and government representatives at conferences and roundtable discussions, to share ideas about current national, regional and global issues. For this purpose, study programmes are also organised on a regular basis. These programmes give experts in certain policy areas the opportunity to find out about the latest trends and developments in the other country, and to discuss common challenges with local experts.

In the area of political dialogue, KAS organises platforms for young politicians and future leaders in policy consultancy (e.g. think tanks, or government-related institutions) to foster exchange on topics that are important for the future of their generation and generations to come, such as digitalisation, education and demographic challenges.

China's urbanisation process also plays an important role in this context. KAS has been working on this topic since 2013, the year when the Federal Chancellor Angela

(c) The Author(s). 2020 Open Access This article is licensed under a Creative Commons Attribution 4.0 International License, which permits use, sharing, adaptation, distribution and reproduction in any medium or format, as long as you give appropriate credit to the original author(s) and the source, provide a link to the Creative Commons licence, and indicate if changes were made. The images or other third party material in this article are included in the article's Creative Commons licence, unless indicated otherwise in a credit line to the material. If material is not included in the article's Creative Commons licence and your intended use is not permitted by statutory regulation or exceeds the permitted use, you will need to obtain permission directly from the copyright holder. To view a copy of this licence, visit http://creativecommons.org/licenses/by/4.0/. 
Merkel and China's Premier Li Keqiang signed the Sino-German Urbanisation Partnership. The aim of KAS' activities in this area is to stimulate a pluralistic debate among local politicians and political advisors on sustainable forms of urbanisation, and to analyse the relevance of German experiences in the field for China.

KAS is also involved in the German-Chinese Rule of Law Dialogue, initiated by the two governments in 2000. Activities in this area currently range from environmental law and civil law, to issues relating to the international settlement of disputes by courts of arbitration. The KAS China offices have already published a number of studies on this matter and undertaken comparisons of German and Chinese law.

Besides legal aspects, another key area of KAS' activities in China is the ecological, financial and technical aspects of climate action and environmental protection. Aspects such as e-mobility and the development of renewable energy are also discussed in this context. The work of KAS in China also focuses on economic issues, such as structural change in the Chinese economy, from an export-dominated model that is environmentally damaging at times, to a sustainable, innovation-driven model. The transformation of China's state-owned enterprises, which continue to be very significant for the Chinese economy, also plays an important role in this discussion.

Digitalisation and the implications resulting from it is also incorporated into the work of the KAS China offices, given that it is a key priority of current policy in both countries. Areas such as e-health, e-learning and e-governance and their practical and legal frameworks and development opportunities are therefore examples of important topics in Sino-German discussions. Bilateral relations have always been an essential pillar of KAS' activities in the field of foreign policy with a reference to foreign policy. Germany and China are strategic partners, and the two countries have held regular Sino-German intergovernmental consultations since 2011. Many of the topics discussed in the process are also used as a basis for discussion for KAS-initiated exchange among representatives from think tanks, academics and party politicians. In this context, KAS cooperates with China's key state and non-state think tanks, and draws on its extensive network in Germany to bring together leading experts from both countries.

In the wake of globalisation and China's growing involvement in the world, which goes beyond trade-related matters and the Belt and Road Initiative, the activities of KAS in China also focus on questions about the role of China in the international system, such as in multilateral institutions, as well as on standards for good governance in the global context. Cooperation between Germany and/or the EU and China in third regions such as Africa also plays an increasingly important role.

Published: 22 April 2020

Reference

1. Samse et al. Asian Journal of German and European Studies (2019) 4:9 Asian Journal of German. https://doi.org/10.1186/ s40856-019-0046-0 